\title{
Effects of Sediment Released from a Check Dam on Sediment Deposits and Fish and Macroinvertebrate Communities in a Small Stream
}

\author{
Rei Itsukushima ${ }^{1,2, * \mathbb{D}}$, Kazuaki Ohtsuki ${ }^{3}$, Tatsuro Sato ${ }^{4}$, Yuichi Kano ${ }^{1}$, Hiroshi Takata ${ }^{5}$ and \\ Hiroaki Yoshikawa ${ }^{6}$ \\ 1 Department of Decision Science for sustainable society, Kyushu University, 744 Motooka, Nishi-ku, \\ Fukuoka 819-0395, Japan; kano@species.jp \\ 2 Department of Transdisciplinary Science and Engineering, Tokyo Institute of Technology, \\ 4259 G5-4 Nagatsuta-cho, Midori-ku, Yokohama 226-8502, Japan \\ 3 Aqua restoration Research Center, Public Works Research Institute, Kawashima Kasada-machi \\ Kakamigahara 501-6021, Japan; k-ootsuki55@pwri.go.jp \\ 4 Disaster Risk Reduction Research Center, Graduate School of Engineering, Kyushu University, 744 Motooka, \\ Nishi-ku, Fukuoka 819-0395, Japan; sato@civil.kyushu-u.ac.jp \\ 5 Department of Urban and Environmental Engineering, Graduate School of Engineering, Kyushu University, \\ 744 Motooka, Nishi-ku, Fukuoka 819-0395, Japan; hirositakata.river@gmail.com \\ 6 CTI Engineering Co., Ltd., 2-4-12, Daimyo, Chuo-ku, Fukuoka 810-0041, Japan; \\ yoshikawa.h.river@gmail.com \\ * Correspondence: itsukushima.r.aa@m.titech.ac.jp; Tel.: +81-45-924-5515
}

Received: 7 March 2019; Accepted: 3 April 2019; Published: 6 April 2019

check for updates

\begin{abstract}
Dam removal is typically intended for river restoration or as a countermeasure for aging dams. The influence of dam removal has mainly been studied in large rivers. This study is intended to investigate the influence of the sediment supplied after opening a check dam drain in a small steep stream to contribute to the establishment of sediment release technology form check dam by accumulating the basic knowledge about the influence of sediment release. Deposited sediment in the impoundment was rapidly discharged immediately after opening the drain outlet, and a moderate sediment discharge followed. The water course of the sediments deposited by repeated channel widening and riverbed degradation tended to stop longitudinal topographic changes from downstream. In addition, the turbidity during a flood was high in the first year and tended to decrease in the second year. As for the ecosystem response, changes in the benthic macroinvertebrate community were confirmed in downstream sites, and net-spinning species especially deceased immediately after the sediment supply began. Our monitoring results suggest that the increasing turbidity was suppressed during the flood because sediment release was conducted from the small-scale facility. As a result, a negative impact on the aquatic ecosystem seemed to be reduced.
\end{abstract}

Keywords: sediment release; geomorphic change; channel evolution; turbidity; ecological response

\section{Introduction}

Changes in the natural flow regime or sediment dynamics after the construction of dams and weirs tend to degrade ecological integrity, cause problems with water utilization, and maintenance of river administration facilities [1,2]. To achieve comprehensive management of a sediment flow system, the whole region of sediment mobilization from the headwater to coast can be monitored $[3,4]$. Recently, the construction of dry dams or open check dams for replenishment of sediment have been applied to enhance the integrity of sediment dynamics in Japan. 
On the other hand, dams have been removed for the sake of river restoration or as a countermeasure for aging dams mainly in the United States [5,6]. Since 1915, 1181 small dams have been removed (1110 of these were lower than $10 \mathrm{~m}$ ), of which $83 \%$ have been removed since 1996 [7]. Monitoring after dam removal includes the erosion process of deposited sediments, channel processes, ecological response, and changes in water quality. The erosion of deposited sediment in the impoundment is known to be determined by the size of deposited grains and the method by which the dam is breached [8-10]. Rapid erosion of deposited sediment occurs when a dam is breached rapidly, and the reservoir sediment is coarse and unconsolidated [11-13]. The large amount of sediment coming from the impoundment following dam removal leads to aggradation of the riverbed, widening of the river channel, decrease in the grain size, filling of pools, or braiding, and flattening of the channel $[10,14-16]$. To monitor the ecological response, fish assemblages, macroinvertebrate communities, and riparian vegetation are frequently measured. Species richness and density of macroinvertebrates have been observed to decrease temporarily and then recover gradually with increasing diversity over a long term [17-20]. Upstream movement of fish such as Salmoniformes or anadromous species has been observed after dam removal [21,22]. Although some studies have reported increasing fish diversity, no direct connection between species diversity of fish and dam removal has been observed, suggesting the need for long-term monitoring [23-25].

The first large-dam removal in Japan was conducted from 2012-2018, and removed the Arase dam in the Kuma River. Following this project, monitoring included geomorphic changes of deposited sediment or downstream channels [26,27], sediment transport characteristics [28], and ecological responses [29]. On the other hand, sediment replenishment downstream of dams is being conducted in different parts of the country, including the investigation of geomorphic change to channels [30-32] and the responses of fish, macroinvertebrates, and algal biomass [33-37]. Further, the sediment transport characteristics of dry dams [38,39], or the comparison of macroinvertebrate fauna of a dry dam and dams with reservoirs have been conducted [40]. Fundamental research about how changes to the sediment flow system affect river morphology or ecological responses is gradually being accumulated.

These evaluations of the effect of sediment release after dam removal or sediment flashing facilities have focused mainly on large rivers. However, in large rivers, factors such as the massive sediment supply from tributaries due to landslides or changing land use in the downstream basin all influence sediment transport, so the effects of the sediment release site are difficult to isolate [41].

We monitored the sediment release in a small watershed where sediment release sites account for $40 \%$ of the whole watershed. Therefore, changes in the sediment dynamics occurring downstream can be assumed to be related to sediment release. In addition, we can monitor the effects of sediment release from the headwater to the river mouth since the river is small. Further, the deposited sediment was released from a small-scale facility with a 1-m-square orifice, so the behavior of the deposited sediment and water quality should differ from that observed in previous studies of dam removal or sediment replenishment. Whereas, check dams have been installed in small rivers nationwide causing the subject of decreasing sediment storage capacity due to sediment deposition. The purpose of this study is to contribute to the establishment of sediment release technology form check dam by accumulating the basic knowledge about the influence of sediment release to the water quality, deposited sediment in the impoundment, or downstream aquatic ecosystem. This paper describes the results of monitoring the behavior of deposited sediment in the impoundment, changes to water quality during a flood, and the biological responses after sediment release from a check dam with 30 years' worth of deposited sediment.

\section{Methodology}

\subsection{Site Location}

We conducted monitoring of the sediment supply in the Kamo River (watershed area: $7 \mathrm{~km}^{2}$, length of flow channel: $6 \mathrm{~km}$, Figure 1). The Kamo River originates in granitic mountains, with high 
active sediment production. The river channel is short and steep, presenting transverse ribs $0.5 \mathrm{~km}$ from the river mouth and a step-pool structure at the upper reach from $0.5 \mathrm{~km}$ with a riverbed slope of $1 / 15$. The riverbed slope is steeper after $2.0 \mathrm{~km}$ with a step-pool structure and large falls. The check dam that supplied sediment is located upstream of this high-gradient segment. The upper reach of the check dam presents an amphitheater formation with a riverbed slope of 1/100 (Figure 2). The check dam was constructed in 1981 at the height of $9 \mathrm{~m}$. Sediment deposition began in the upper area of the check dam because of the impoundment of the check dam. A 1-m-square drainage outlet with a hydraulic gate was installed under the spillway section. However, the hydraulic gate structure failed 30 years ago, and sediment deposition has become advanced. In collaboration with local residents wanting to restore water quality and the river environment, we opened the check dam drain outlet. After water discharge from the impoundment, the check dam drain outlet was opened on 4 March 2017. A water route formed in the deposited sediment in the impoundment, and the deposited sediment began to flow downstream of the check dam.

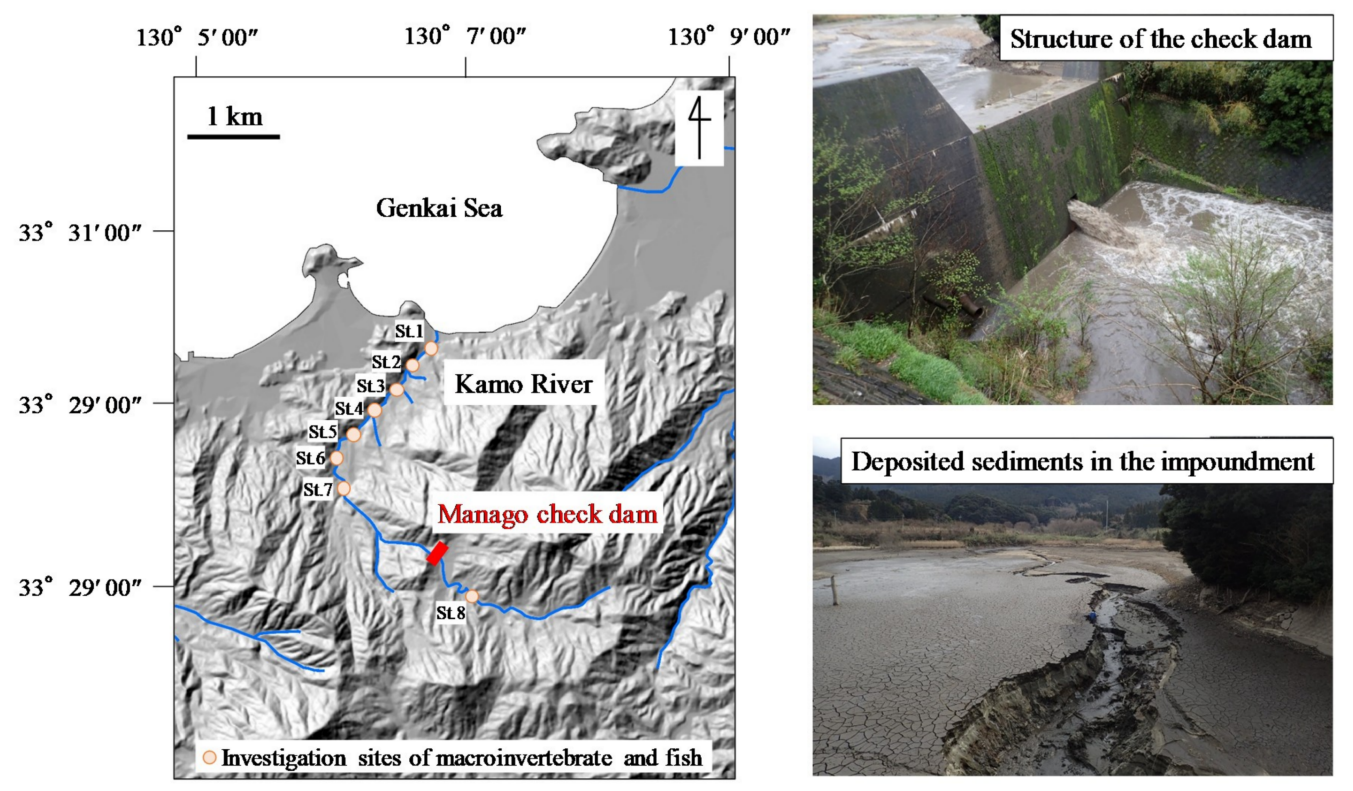

Figure 1. Location map showing the Kamo River investigated in this study.

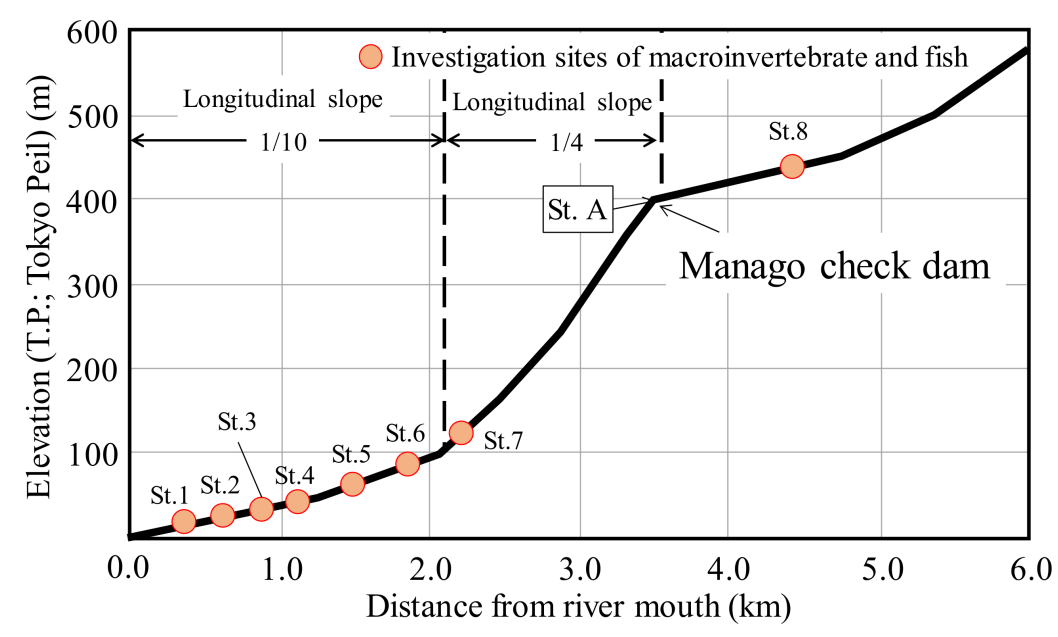

Figure 2. Longitudinal profile of the Kamo River.

\subsection{Geomorphic Changes of Deposited Sediment}

We conducted a topographic survey to evaluate geomorphic changes in the deposited sediment in the impoundment. This survey involved sectional and longitudinal surveys of the water course 
at all stations before opening the check dam drain outlet (16 June 2016) and a sounding survey at 125 points after opening the check dam drain outlet (14 March, 19 June, 14 July and 19 November 2017, 27 March and 19 July 2018 and 22 February 2019). Further, we collected airborne imagery using a UAV (Unmanned Aerial Vehicle; Da-Jiang Innovations Science and Technology Co., Ltd., Phantom 3, Shenzhen, China) flying $30 \mathrm{~m}$ above the river on 14 March and 8 June 2017, 12 December and 30 March 2018, and 20 February 2019. DEM (Digital Elevation Model) and orthographic satellite images were created using the SfM (Structure from Motion) analysis with the PhotoScan Professional software (Agisoft Co., Ltd., St. Petersburg, Russia). The elevation of some areas could not be estimated due to plant growth without erosion, so we used DEM data collected before plant growth after confirming the absence of erosion.

\subsection{Characteristics of Sediment Transport}

To evaluate sediment runoff and the characteristics of sediment transport from the check dam impoundment, we collected water samples during floods with continuous observations using a turbidimeter. A turbidimeter (JFE Advantech CO., Ltd., Nishinomiya, Japan) and water gauge (Onset Cmputer Corporation, Borne, MA, USA) were installed at St. A (Figure 2). Further, we measured the suspended solid concentration during the flood stage from water samples. Continuous turbidity observations were transformed to suspended solid concentrations using a regression equation. Suspended solid concentration measurements followed the method in JIS (Japanese Industrial Standard) K0102 14.1 [42].

\subsection{Sampling of Aquatic Community}

To evaluate the effects of sediment supplied from the check dam, we captured benthic invertebrates from the Kamo River. We installed eight investigation stations including a reference site located upstream of the check dam (Figures 1 and 2). We selected a $50 \mathrm{~m}$ reach and captured invertebrate species in rapids, runs and pools each investigation site. We collected invertebrates over 30 min working with four people using surber nets so that the sampling was consistent across surveys (net length $0.51 \mathrm{~m}$, mesh size $0.3 \mathrm{~mm}$ ). The sampled invertebrates were preserved in $80 \%$ ethanol in the field and were identified later by Plantbio Co., Ltd. Macroinvertebrates were sampled in seven seasons during two years.

Fish were sampled in the same reach as the benthic invertebrate survey. All the fish were collected in a single pass with the Smith-Root LR-24 backpack electrofisher (Smith-Root Inc., Vancouver, WA, USA) and a fish landing net. The sampled fish were identified in the field and released at the captured investigation site. Fish were sampled in six seasons over two years.

\subsection{Statistical Analysis}

To evaluate the sediment supplied from the check dam, we analyzed the benthic macroinvertebrate and fish fauna at each station using NMDS (Non-Metric Multi-Dimensional Scaling) [43]. In addition, the similarity of benthic macroinvertebrates and fish fauna were calculated with the Bray-Curtis similarity index [44]. Further, to evaluate seasonal changes in species diversity, we calculated the Shannon-Wiener diversity index [45].

\section{Results and Discussion}

\subsection{Runoff of Deposited Sediment and Topographic Changes}

As revealed by SfM analysis of the aerial photographs collected by UAV, the largest topographic change occurred immediately after the beginning of the sediment supply and was concentrated around the vicinity of the drain outlet (Figure 3). After several floods, the ground level mainly declined around the water course. On 8 June 2017, ground level degradation reached cross section 2 . After the flood season, no significant change in the topography occurred in autumn or winter. Ground level 
degradation progressed again during flood season of the second year, and degradation reached cross section 3. Further, the water course had meandered near cross section 3, suggesting a large topographic change.

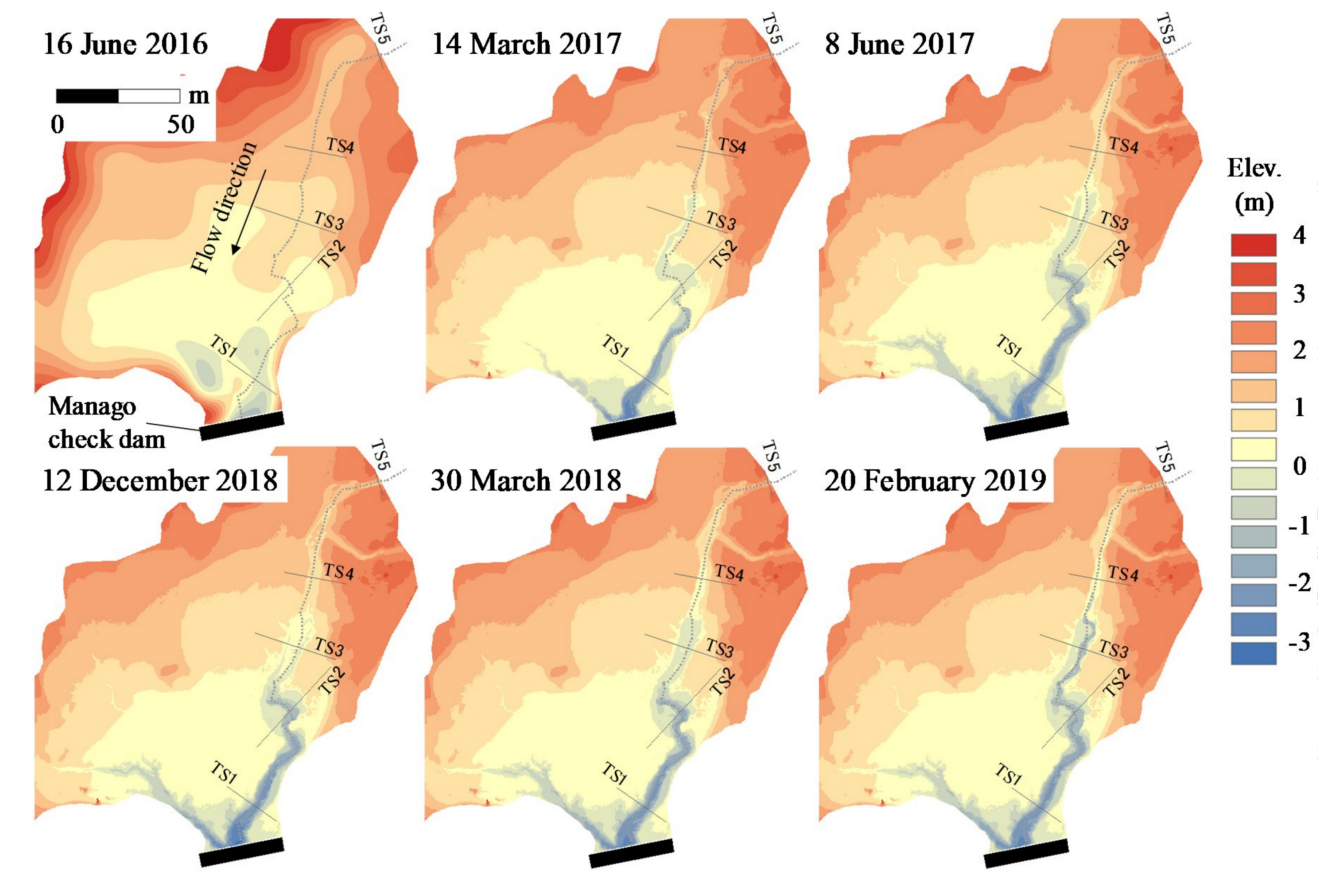

Figure 3. Topographic change on different months of deposited sediment in the impoundment of the Manago check dam.

In addition, the longitudinal formation of the water course declined significantly immediately after the drain outlet was opened (Figure 4). Further, the longitudinal profile was characterized by sudden change of the gradient accompanied by steps due to the resistance from rootstock. The riverbed elevation had degraded by the discharge of deposits in the upper reach of the steps since the steps collapsed during the flood. The topographic change in the longitudinal direction indicated that degradation near the drain outlet immediately after it was opened spread to the upper reach, which restricted erosion from downstream. Since the ground elevation did not change significantly except for around the water course from June 2017 to February 2019 (Figure 3), most of the sediment discharge was likely accompanied by riverbed degradation. On the other hand, the cross-section profile of TS 1, located furthest downstream, was degraded and had widened immediately after the drain outlet was opened. However, no significant change was observed after 4 March 2017. At TS 2 to 4 , the cross-section profile changed with repeated degradation and widening. In contrast, no large widening occurred and the tendency of erosion prominence was confirmed at TS 5, located at the most-upstream part of the river (Figure 5).

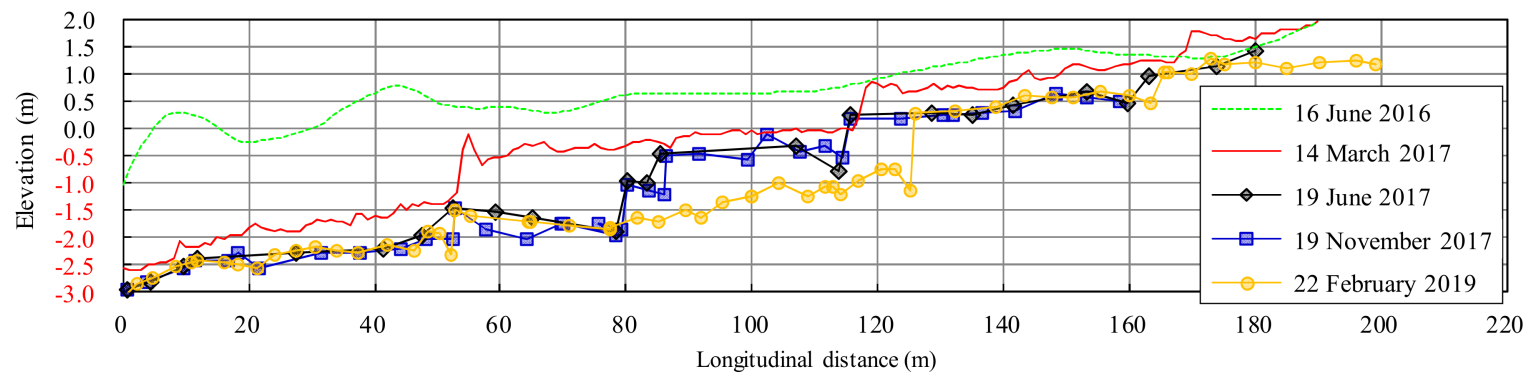

Figure 4. Time change of longitudinal profile of the water course in the deposited sediment. 


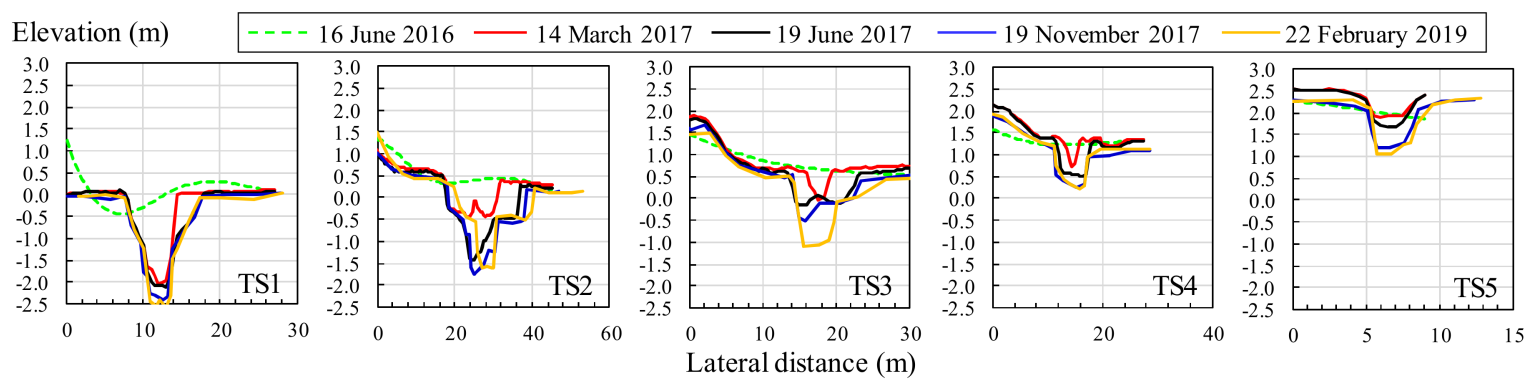

Figure 5. Time change of cross section profile of the water course in the deposited sediment.

The greatest sediment discharge occurred in the 10 days after opening the drain outlet, accounting for $18.4 \%$ of the sediment deposited in the impoundment. After that, moderate sediment discharge occurred, and $20.3 \%$ of the deposited sediment in the impoundment was discharged over the 718 days after opening the outlet (Figure 6). Relative to the sediment discharge rates measured from other cases of dam removal, the tendency of sediment discharge is similar in cases in which fine sediment was observed (composed of over 30\% of silt and clay) [8-10]. This effect is expected, since the median diameter of 20 samples of deposited sediment in the impoundment observed in this study was $0.027 \pm 0.019 \mathrm{~mm}$ (median \pm interquartile range), and the content of silt and clay (particle size $<0.074$ ) was $77.0 \pm 39.5 \%$ (median \pm interquartile range). In addition, runoff from the deposited sediment has been observed to be restricted in cases of gradual dam removal $[46,47]$. In the present study, deposited sediment was discharged from the relatively small 1-m-square drain outlet, therefore, any sudden large discharge was avoided.

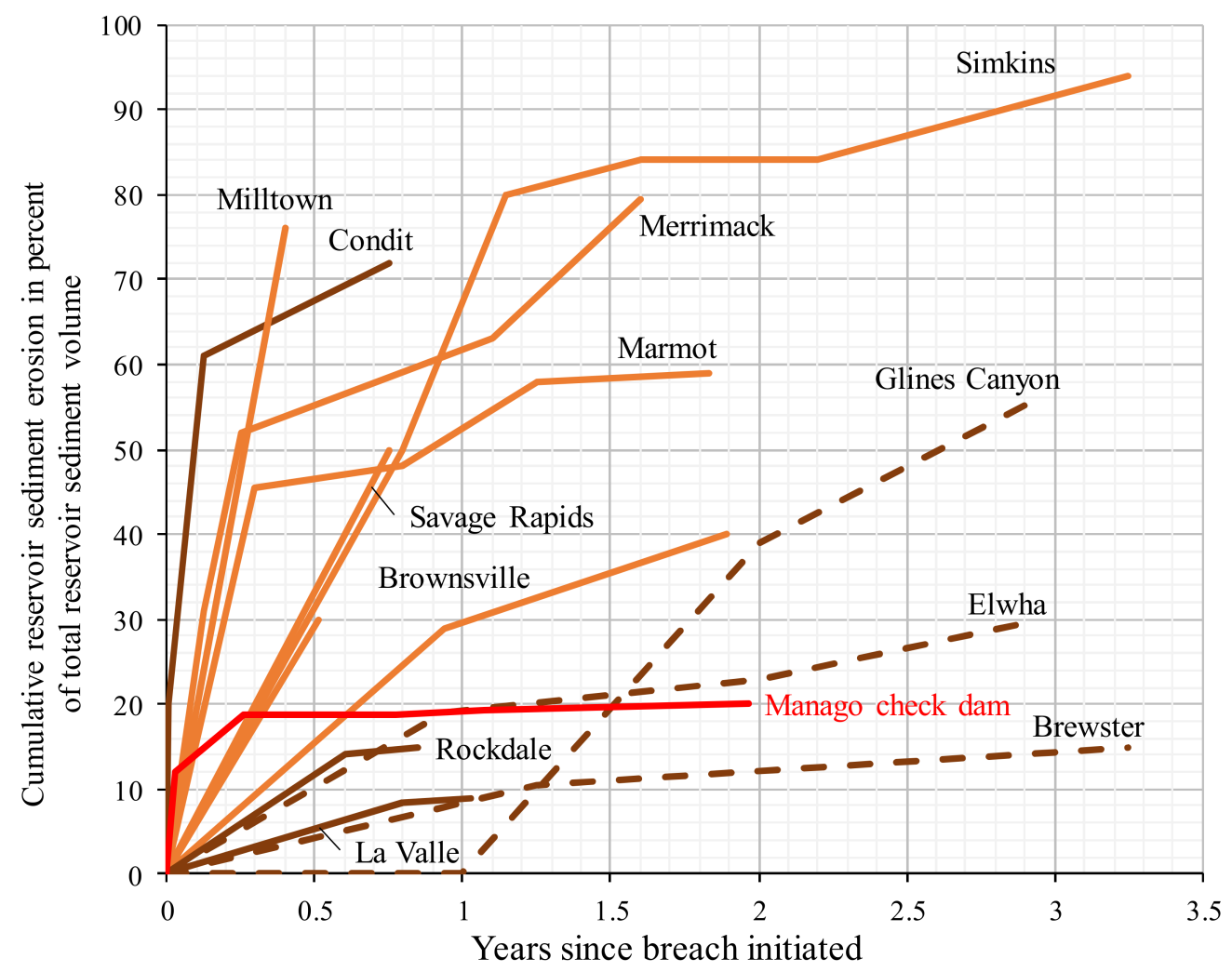

Figure 6. Percentage of reservoir sediment eroded with time after dam removal. Comparison between the Manago check dam and other sites of dam removal. Modified from Major et al., 2017 [10]; Sawaske and Freyberg, 2012 [8]; Grant and Lewis 2015 [9]; Foley et al., 2017 [48]. 
As for topographic changes after opening the check dam drain outlet, both widening of the river channel and riverbed degradation were confirmed in TS 2-4. In hydraulic model experiments aiming to predict the topographic change after dam removal, the river width narrowed after sudden riverbed degradation and widened after more gradual riverbed degradation [49]. The channel widening and riverbed degradation observed in this study may indicate a process of riverbed degradation caused by sediment discharge after floods and riverbank erosion after the abrupt decrease of roughness coefficients. In addition, the transport process of deposited sediment can be classified into two stages: An initial process in which a large amount of cohesive sediment discharges and a later process that includes sediment discharge due to relatively large floods that exceed the riverbank [13]. Deposited sediment on the riverbank was not also discharged during normal-level floods at other dam removal sites $[50,51]$. Our results indicate that no large amount of deposited sediment on the riverbank was discharged, which means that a large flood may be needed to transport these sediments.

We assumed that the released sediment flows to the estuaries without deposition in the river channel since the Kamo River is steep gradient. However, the released sediment deposited in the river bank or pool especially in the high gradient channel a short distance downstream from the check dam [41]. In addition, deposited sediment was observed to gradually move downstream. The sediment deposition in the river channel suggested that the released sediment lead to change the topography of the river channel or bottom characteristics even in the steep slope channel.

\subsection{Characteristics of Sediment Transport}

Monitoring water level, flow discharge and turbidity at Station A, located a short distance upstream from the drain outlet, during 2017 and 2018 is shown in Figure 7. The turbidity values observed in 2018 were generally lower than the turbidity in 2017 [41], although the maximum flood discharge was larger than it was in 2017. This difference is explained by the observation that most of the fine sediment particles that contributed to the increasing turbidity appeared immediately after the check dam drain outlet was opened in 2017. However, since the turbidity was not recorded with sufficient accuracy because iron was attached during the observation, this measurement is considered only as a reference value.
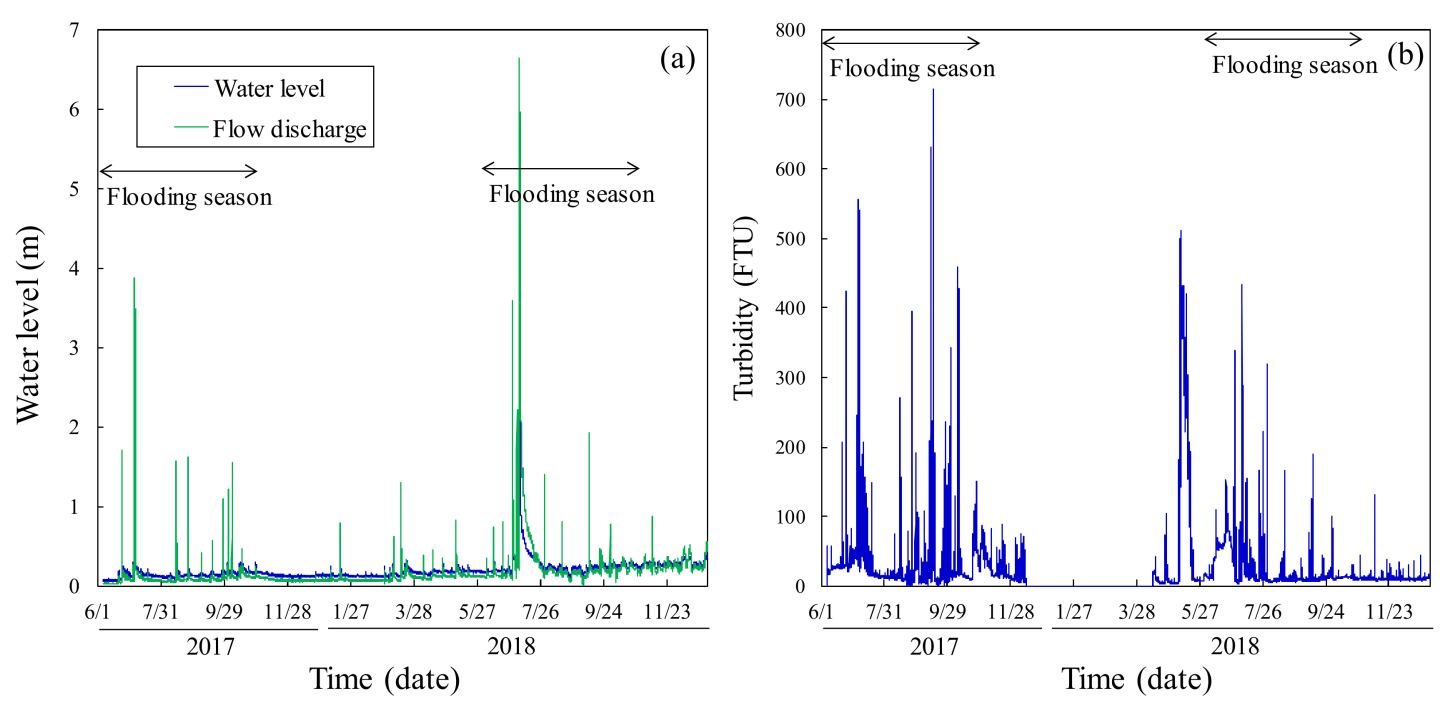

Figure 7. Time change of water level, flow discharge, and turbidity (St. A). (a) Water level (b) turbidity.

The relationship between flow discharge and turbidity in each year is indicated in Figure 8. The turbidity value for the same flow discharge was larger in 2017 than in 2018, when comparing the relationship between the peak values of turbidity and flow discharge. The largest flood observed during the monitoring period occurred in 2018, however, the value of turbidity did not increased much. In addition, a clockwise loop in the relationship between water level and turbidity was observed during 
the larger floods (Figure 9). During the large flood of 6 July 2017, the value of turbidity decreased suddenly as the water level increased. This trend was also observed during the flood of 6 July 2018. The structure of the drain outlet conducting the sediment supply seems to explain this trend. The drain outlet is $1 \mathrm{~m}$ over from the riverbed, so when the water level rises above the drain outlet, the attractive force decreased because of the backwater, leading to the sudden decrease in turbidity.

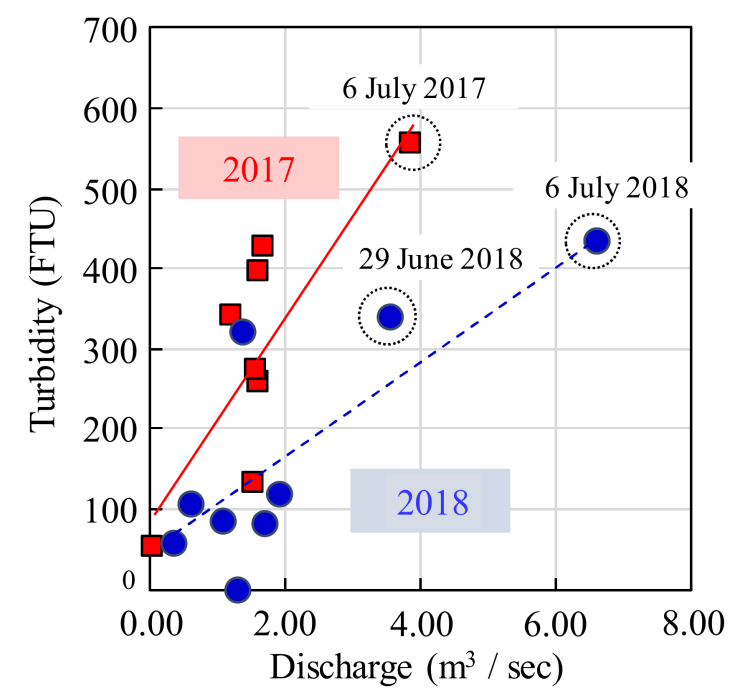

Figure 8. Relationship between turbidity and flow discharge (St. A).
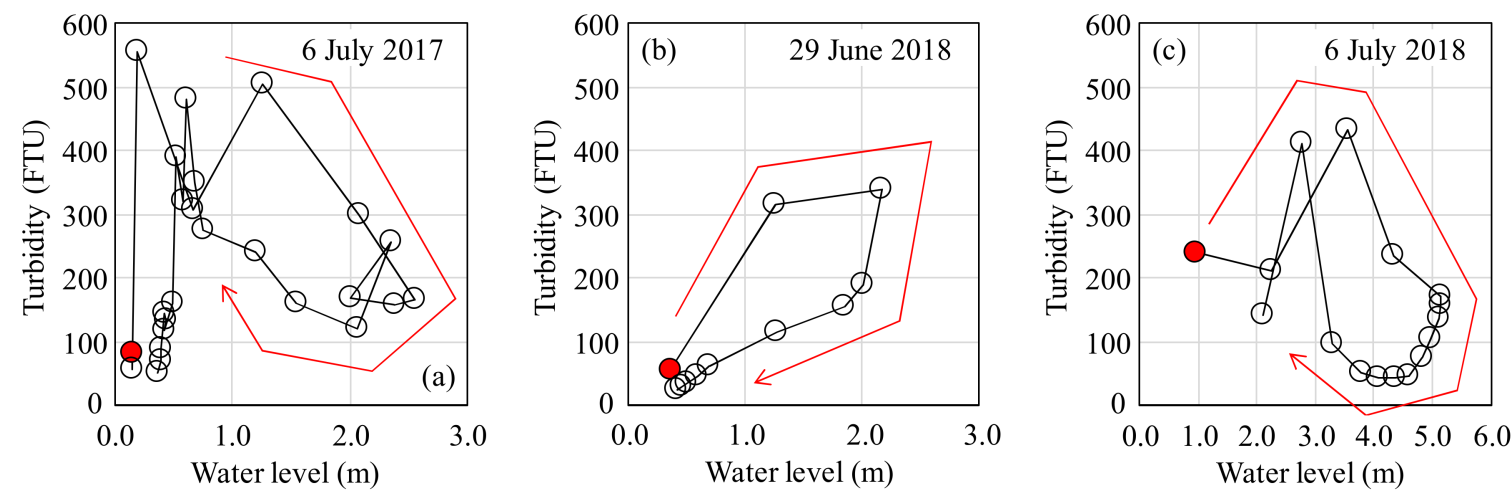

Figure 9. Time change of turbidity and flow discharge during flood (St. A). (a) 6 July 2017, (b) 29 June 2018, (c) 6 July 2018.

Next, we discuss the relationship between the suspended solid concentration and the particle size of transported sediment. Figure 10 shows the change in particle size and suspended solid concentration over time, during the flood of 24 June 2017. During the period of increasing flow discharge, most of the transported sediment was silt and the ratio tended to increase along with the increasing concentration of suspended solids. On the other hand, the proportion of sand increased during the stage of peak flow discharge when the suspended solid concentration exceeded $1000 \mathrm{mg} / \mathrm{L}$. The ratio of silt increased again during the period of decreasing flow discharge. 


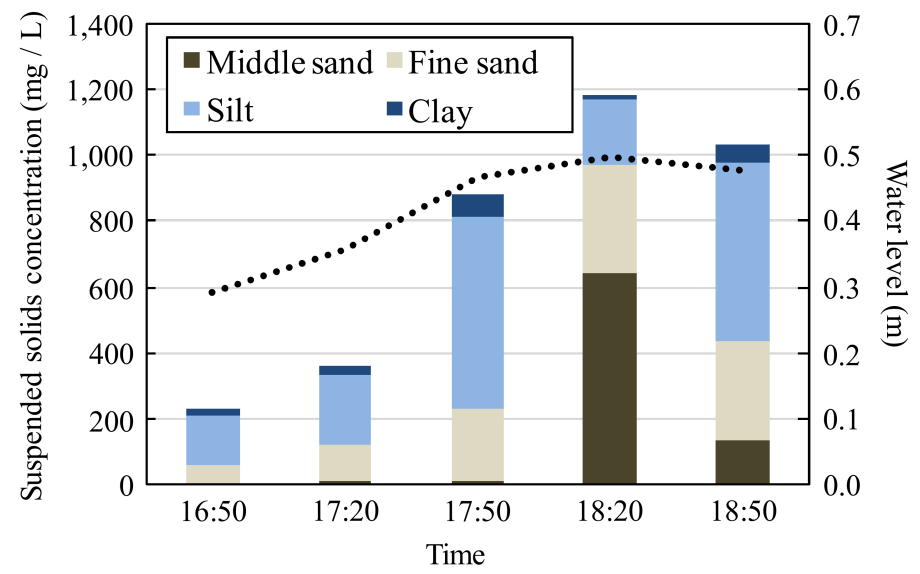

Figure 10. Mass composition of flushed suspended sediment (St. A, 24 June 2017).

\subsection{Seasonal Change of Benthic Macroinvertebrate Assemblage}

In total, 12 orders, 60 families, 152 species, and 5283 individual microinvertebrates were collected in the seven surveys taken at eight sites. Baetis thermicus belonging to Baetidae was the most-collected species with 1155 individuals, followed by Cincticostella elongatula belonging to Ephemerellidae with 608 individuals. Station seven was associated with the highest number of species in the summer of 2017 and the spring of 2018 (36 species). In addition, the most-downstream station was associated with the lowest number of species immediately after the beginning of the sediment supply (10 species).

We collected 56 (eight stations in seven seasons) macroinvertebrate samples, which were classified into four groups and plotted according to the NMDS grade level (Figure 11). This cluster analysis showed that macroinvertebrate assemblages at the reference site (Station 8) upstream of the check dam were classified into the different groups of macroinvertebrates located downstream of the check dam. On the other hand, macroinvertebrate assemblages collected from Stations 4-7 were classified into spring and summer seasons (Group B) and autumn and winter seasons (Group C), suggesting that the macroinvertebrate species change seasonally. Macroinvertebrate assemblages at Station 1-3 were mainly classified into Group D, Group B and Group C, and were composed of macroinvertebrates from Stations 4-7.

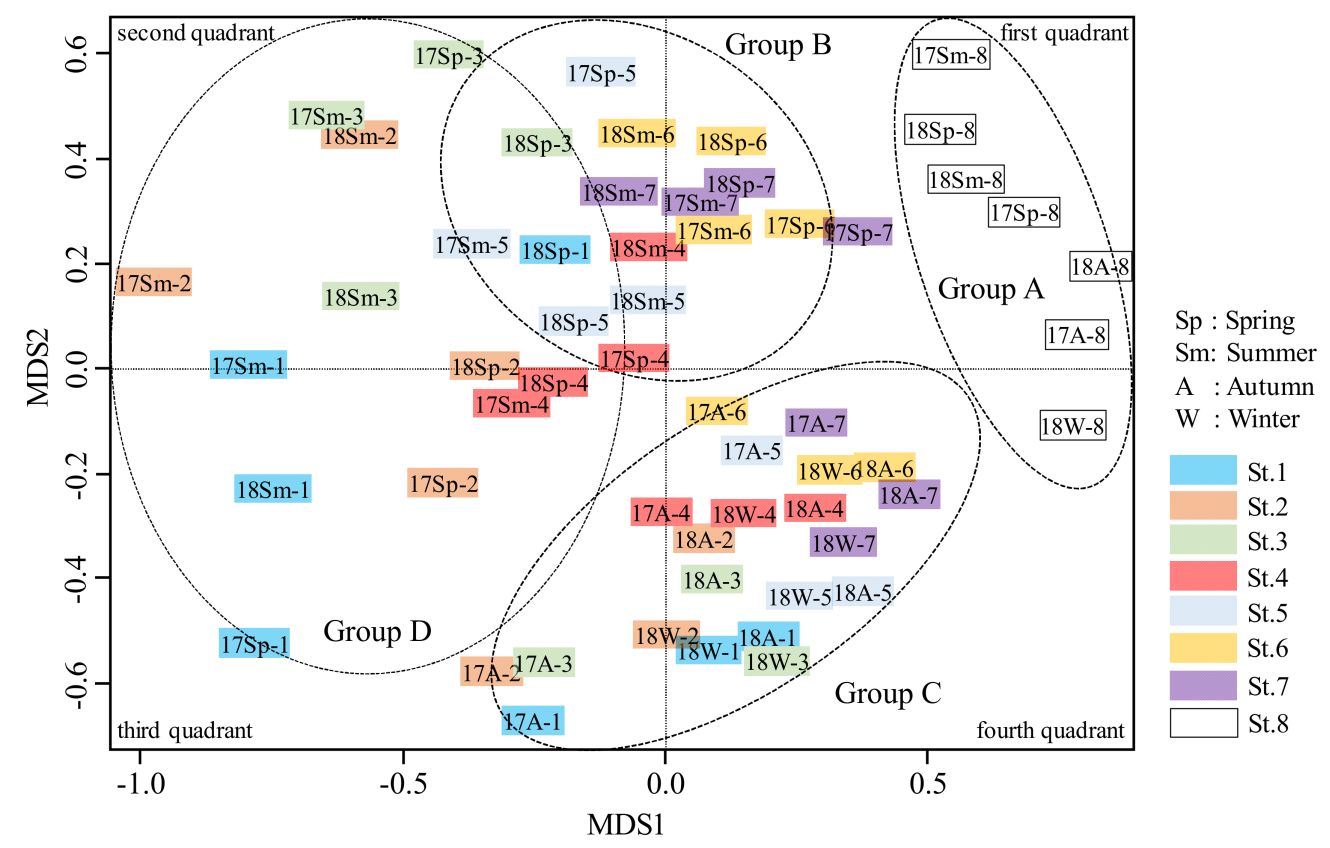

Figure 11. NMDS for similarity between stations on benthic macroinvertebrate community in the Kamo River. 
In the NMDS results, the investigation sites upstream of the check dam (Group A) were located in the first quadrant, Group B were located in the second quadrant, Group C were located in the fourth quadrant, and Group D were located in the second and third quadrants. Considering the results of cluster analysis, the first axis of NMDS indicates changes at the investigation site (positive direction-upstream, negative direction-downstream), and the second axis of NMDS indicates the difference in seasons (positive direction—spring and summer, negative direction—autumn and winter). The macroinvertebrate assemblages collected at Stations 1 and 2 in spring and summer were in the negative region of the NMDS plot, which originally indicated the macroinvertebrate assemblages collected in autumn and winter. In addition, the macroinvertebrate assemblages from Stations 1 and 2 collected in autumn and winter of 2018, some time after the beginning of sediment supply, were classified into Group $C$ which was composed of the macroinvertebrate assemblages from Stations 4-7 in autumn and winter, while the macroinvertebrate assemblages collected from Stations 1 and 2 immediately after beginning of sediment supply were different from those collected from the other investigation stations.

Figure 12 indicates the change over time of the Shannon-Wiener diversity index from each station. The diversity index was the lowest in the downstream stations immediately after the sediment supply began. The diversity index tended to recover with time. In addition, the diversity index decreased in the survey taken during winter 2018 at all stations. We suppose that this decrease was caused by annual fluctuations since the diversity index decreased even though this station was not affected by the sediment supply (Station 8 ). Comparison of seasonal changes based on the life-type concept, the abundance of net-spinning species decreased $(70 \% \rightarrow 37 \%)$ in the lowest station (1) and the abundance of burrowers increased $(8 \% \rightarrow 26 \%)$ in the second-lowest station (2) between spring and summer of 2017, when the amount of sediment was highest of all times in the monitoring period. In addition, comparison of the functional feeding groups indicated increasing populations of filter feeders $(72 \% \rightarrow 39 \%)$ in the lowest stations. This result confirms the change of habitat, such as filling the pools at the lowest stations with fine sediments. Overall, the macroinvertebrate community structure was affected by the sediment supply.

Sedimentation of habitats due to the removal of dams has been reported to decrease the density and taxonomic richness of downstream macroinvertebrates, which subsequently recover $[18,20]$. In this study, we found that macroinvertebrate species diversity declined immediately after the beginning of sediment supply and that it recovered after one year (Figure 12). In addition, long-term monitoring of macroinvertebrate communities has suggested that macroinvertebrate density and diversity tend to recover after dam removal, especially during seasons in which macroinvertebrate density is typically lowest [19]. We cannot confirm this trend, and further long-term monitoring will be necessary to reveal the relationship between sediment supply and macroinvertebrate community response. Even so, a significant decline in net-spinning species was observed immediately after the sediment supply. In rivers degraded by decreasing sediment supply after dam construction, macroinvertebrate fauna tend to be dominated by net-spinning species [52-54]. Therefore, decrease in the prevalence of net-spinning species and increase in the prevalence of swimmers indicates the restoration of the integrity of macroinvertebrate fauna following sediment supplied by opening the check dam drain outlet. 


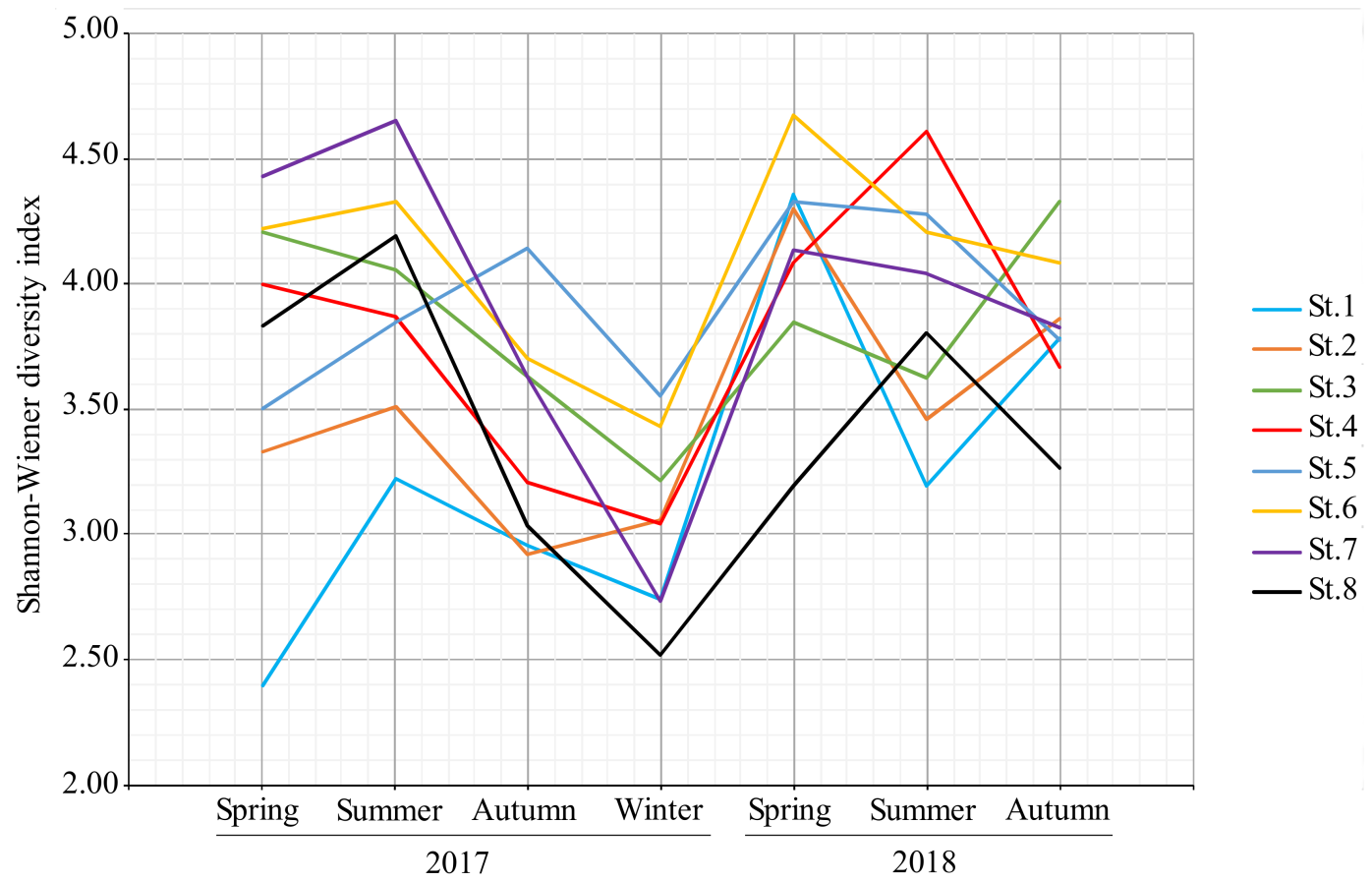

Figure 12. Time change of Shannon-Wiener diversity index of each stations in the Kamo River (macroinvertebrate community).

\subsection{Seasonal Variation of Fish Fauna}

In total, five orders, six families, 18 species, and 3355 individual fish were collected in six surveys at eight sites. Candidia temminckii belonging to Cyprinidae was the most-collected species with 1366 individuals, followed by rhinogobius fluviatilis belonging to Gobiidae with 471 individuals. Stations 1 and 2 in the summer and Station 1 in the autumn of 2017 had the highest numbers of species (10 species). In addition, the numbers of species increased longitudinally from upstream to downstream.

We collected 48 (eight stations by six seasons) samples of fish fauna which were classified four groups and plotted using NMDS (Figure 13). Cluster analysis showed that the fish fauna of the Kamo River can be classified into four groups along the longitudinal direction. Fish collected at stations located upstream of the check dam that supplied sediment are classified into Group A, unlike those collected from other stations. On the other hand, Group B is composed of stations located upstream (6 and 7), Group C is composed of stations located midstream (3, 4 and 5), and Group D was downstream (1 and 2).

The NMDS analysis showed that the investigation sites upstream of the check dam (Group A) were located in the fourth quadrant, Group B were located in the first quadrant, Group C were located in the second and third quadrant, Group D were located in the third quadrant. Considering the result of cluster analysis, the first axis of NMDS indicates the change of investigation site along the longitudinal direction (positive direction-upstream, negative direction—downstream), and the second axis of NMDS indicates the change of seasons (positive direction-spring and summer, negative direction-autumn and winter). The plotted position of Station 1 in the NMDS grade level changed with the seasons along the first axis, because the fish fauna at Station 1 varied more than those at other stations due to the incidental incursion of saltwater fish like mugil cephalus cephalus. 


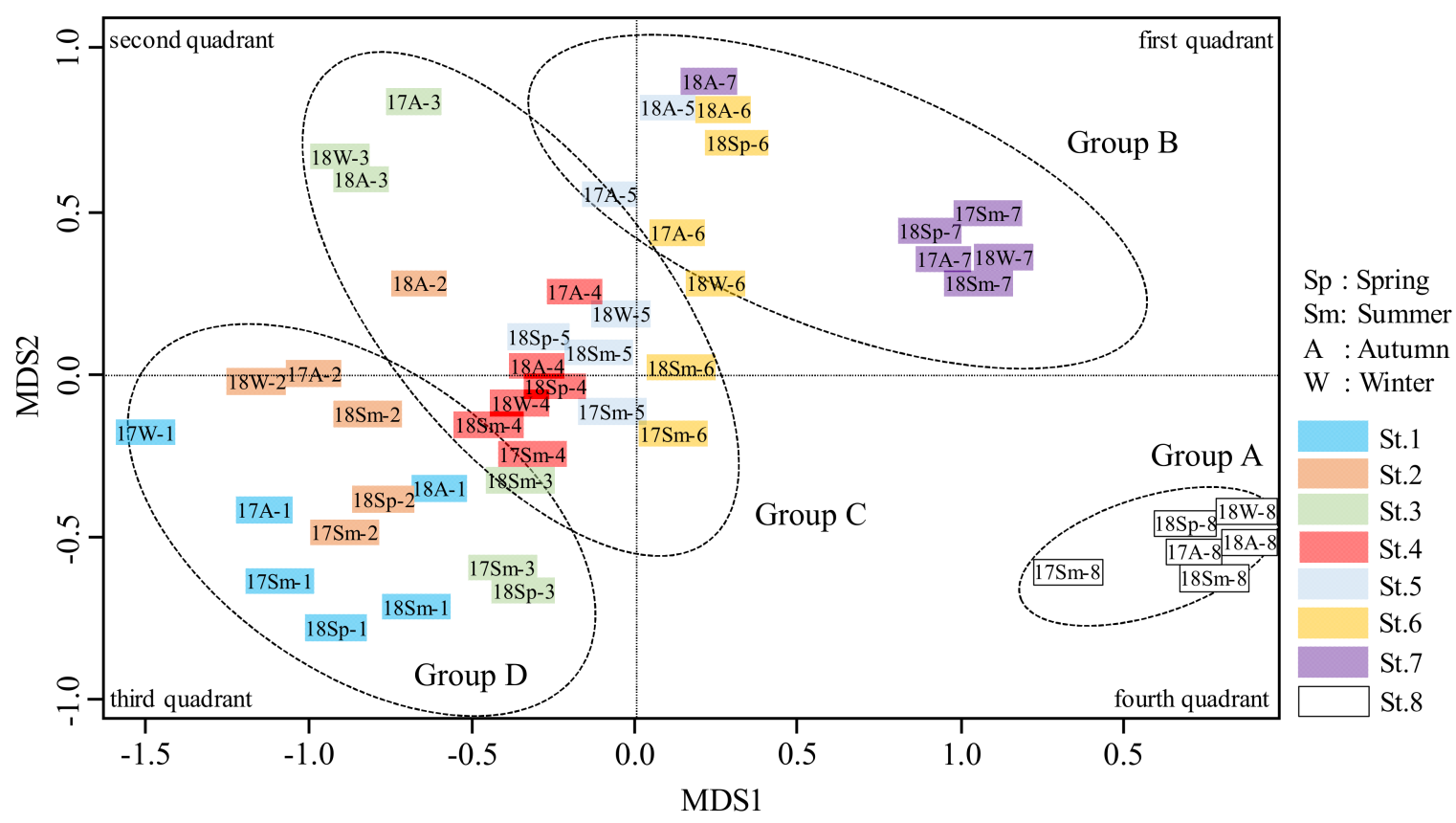

Figure 13. NMDS for similarity between stations on fish fauna in the Kamo River.

Figure 14 indicates the change over time of the Shannon-Wiener diversity index for the fish at each station. The index was the highest in the summer and decreased in the autumn and winter; data from all stations followed this trend. The index was the lowest in the autumn of 2018, but since this tendency was common to all stations, it likely indicates annual variation. We did not observe that species composition was affected by sediment supply from opening the check dam drain outlet.

The increased suspended solid concentration following sediment supply greatly affects fish populations. Hatching and development of fish and molluscan species are known to be influenced by the suspended solid concentration $[55,56]$. In addition, the response of fish to increasing suspended solid concentrations after sediment supply indicate that salmonidae species can survive in concentrations of suspended solid of about $8000 \mathrm{mg} / \mathrm{L}$ for a few days [57]. In this study, the peak value of suspended solid concentration was about $1200 \mathrm{mg} / \mathrm{L}$, which had no effect on the survival of fish species. Therefore, no substantial shift in fish fauna was observed. Further, communities of fish in streams may respond to changes in sediment supply after dam removal if the dam removal is executed just before the flood season [20]. Therefore, the management of suspended solid concentration and control of the timing of sediment supply is important in mitigating the impacts of dam alterations.

In this paper, we described the relationship between aquatic organisms and sediment or water quality because the high concentration of suspended solid was confirmed immediately after the sediment release. However, community structure will be changed due to the alternation of habitat physical environment by sediment release in a longer time. We plan to continue monitoring the relationship between community structure and physical environment of the habitat. 


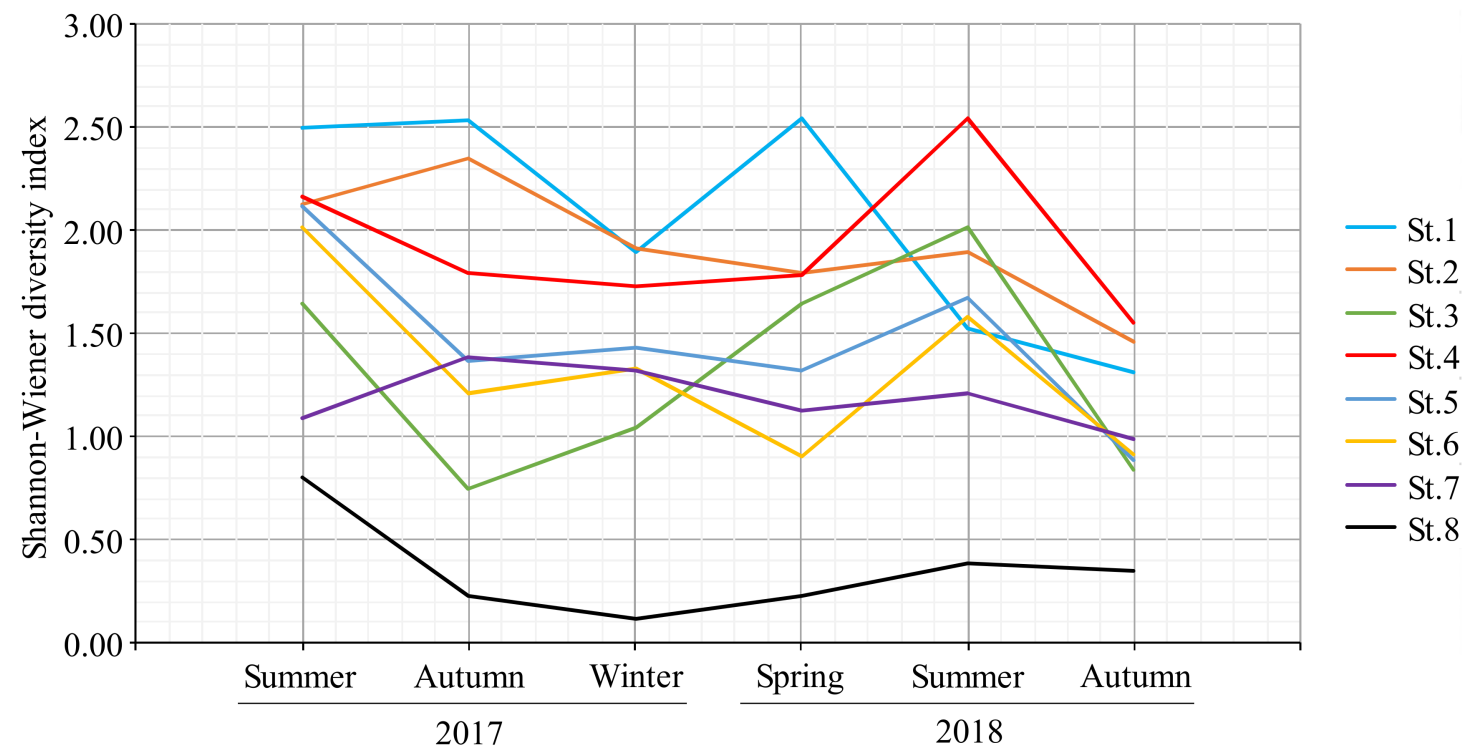

Figure 14. Time change of Shannon-Wiener diversity index of each stations in the Kamo River (fish fauna).

\section{Conclusions}

This study aimed to investigate the influence of sediment supplied by opening a check dam drain outlet on the topography of deposited sediment, downstream sediment transport, and the response of aquatic ecosystems. Three main conclusions follow from our observations:

1. Deposited sediment held in the impoundment was discharged rapidly immediately after the drain outlet was opened, and moderate sediment discharge followed. The introduction of deposited sediments led to repeated channel widening and riverbed degradation, which tended to prevent longitudinal topographic changes downstream.

2. Turbidity during floods was high in the first year and tended to decrease in the second year. The behavior of turbidity downstream of the check dam depended on the structure of the drain outlet, and the turbidity decreased suddenly when the water level exceeded the height of the drain outlet.

3. Changes in the benthic macroinvertebrate community were confirmed at the downstream sites. Net-spinning species especially decreased immediately after the sediment supply began. The fish fauna was not changed by the sediment supply.

4. Our monitoring result suggests that the increasing turbidity was suppressed during the flood because sediment release was conducted from the small-scale facility. As a result, a negative impact on the aquatic ecosystem seem to be reduced, whereas, fully sediment release from impoundment required much more time. Further investigation of the relationship between sediment release structure and amount of released sediment is required to identify the optimum structure for sediment release.

Author Contributions: R.I. directed the research program and wrote this paper. K.O. monitored sediment transport. T.S. investigated the topographic change of the deposited sediment. Y.K. investigated the aquatic ecosystem. H.T. conducted SfM analysis and field surveys. H.Y. conducted topographic surveys.

Funding: This research was funded by the Water Resources Environment Center grant number 2017-01.

Conflicts of Interest: The authors declare no conflict of interest.

\section{References}

1. Poff, N.L.; Allan, J.D.; Bain, M.B.; Karr, J.R.; Prestegaard, K.L.; Richter, B.D.; Sparks, R.E.; Stromberg, J.C. The natural flow regime: A paradigm for river conservation and restoration. BioScience 1997, 47, 769-784. [CrossRef] 
2. Tsujimoto, T.; Fujita, K. On scenario-driven research and development toward the integrated management of the river-basin-scale sediment transport system. Adv. River Eng. 2004, 10, 13-18.

3. Miyamoto, H.; Suzuki, N. Sediment control of a water reservoir at dams. Proc. JSCE. II Hydraul. Sanit. Eng. 2003, 740, 185-195.

4. Mizuyama, T. Sediment production, transport, sediment control and sabo in river basins. Proc. JSCE. II Hydraul. Sanit. Eng. 2004, 754. [CrossRef]

5. Center, H. Dam Removal Science and Decision Making; The H. John Heinz III Center for Science, Economics, and the Environment: Washington, DC, USA, 2002.

6. Pohl, M.M. Bringing down our dams: Trends in American dam removal rationales. J. Am. Water Resour. Assoc. 2002, 38, 1511-1519. [CrossRef]

7. American Rivers. American Rivers Dam Removal Database 2016. Available online: http://www. americanrivers.org/initiative/dams/projects/2014-dam-removals (accessed on 15 February 2019).

8. Sawaske, S.R.; Freyberg, D.L. A comparison of past small dam removals in highly sediment-impacted systems in the U.S. Geomorphology 2012, 151-152, 50-58. [CrossRef]

9. Grant, G.E.; Lewis, S.L. The remains of the dam: What have we learned from 15 years of us dam removals? Engineering Geology for Society and Territory, 3: River Basins. Reserv. Sediment. Water Resour. 2015, 3, 31-38.

10. Major, J.J.; East, A.E.; O'Connor, J.E.; Grant, G.E.; Wilcox, A.C.; Magirl, C.S.; Collins, M.J.; Tullos, D.D. Geomorphic responses to dam removal in the United States-A two-decade perspective. In Gravel-Bed Rivers: Processes and Disasters; Tsutsumi, D., Laronne, J., Eds.; Wiley and Sons: Hoboken, NJ, USA, 2017; pp. 355-383.

11. Pearson, A.J.; Snyder, N.P.; Collins, M.J. Rates and processes of channel response to dam removal with a sand-filled impoundment. Water. Resour. Res. 2011, 47, 7204. [CrossRef]

12. Wilcox, A.C.; O'Connor, J.E.; Major, J.J. Rapid reservoir erosion, hyperconcentrated flow, and downstream deposition triggered by breaching of $38 \mathrm{~m}$ tall Condit Dam, White Salmon River, Washington. J. Geophys. Res. Earth Surf. 2014, 119, 1376-1394. [CrossRef]

13. Collins, M.J.; Snyder, N.P.; Boardman, G.; Banks, W.S.L.; Andrews, M.; Baker, M.E.; Conlon, M.; Gellis, A.; McClain, S.; Miller, A.; et al. Channel response to sediment release: Insights from a paired analysis of dam removal. Earth Surf. Proc. Land. 2017, 42, 1636-1651. [CrossRef]

14. Harris, N.; Evans, J.E. Channel Evolution of Sandy Reservoir Sediments Following Low-Head Dam Removal, Ottawa River, Northwestern Ohio, USA. Open J. Mod. Hydrol. 2014, 4, 44-56. [CrossRef]

15. East, A.E.; Pess, G.R.; Bountry, J.A.; Magirl, C.S.; Ritchie, A.C.; Logan, J.B.; Randle, T.J.; Mastin, M.C.; Minear, J.T.; Duda, J.J.; et al. Large-scale dam removal on the Elwha River, Washington, USA: River channel and floodplain geomorphic change. Geomorphology 2015, 228, 765-786. [CrossRef]

16. Zunka, J.P.P.; Tullos, D.D.; Lancaster, S.T. Effects of sediment pulses on bed relief in bar-pool channels. Earth Surf. Proc. Land. 2015, 40, 1017-1028. [CrossRef]

17. Kil, H.K.; Bae, Y.J. Effects of low-head dam removal on benthic macroinvertebrate communities in a Korean stream. Anim. Cells Syst. 2012, 16, 69-76. [CrossRef]

18. Chiu, M.C.; Yeh, C.H.; Sun, Y.H.; Kuo, M.H. Short-term effects of dam removal on macroinvertebrates in a Taiwan stream. Aquat. Ecol. 2013, 47, 245-252. [CrossRef]

19. Sullivan, S.M.P.; Manning, D.W.P. Seasonally distinct taxonomic and functional shifts in macroinvertebrate communities following dam removal. PeerJ 2017, 5, e3189. [CrossRef] [PubMed]

20. Chang, H.Y.; Chiu, M.C.; Chuang, Y.L.; Tzeng, C.S.; Kuo, M.H.; Yeh, C.H.; Wang, H.W.; Wu, S.H.; Kuan, W.H.; Tsai, S.T.; et al. Community responses to dam removal in a subtropical mountainous stream. Aquat. Sci. 2017, 79, 967-983. [CrossRef]

21. Izzo, L.K.; Maynard, G.A.; Zydlewski, J. Upstream movements of Atlantic salmon in the lower Penobscot River, Maine following two dam removals and fish passage modifications. Mar. Coast. Fish. 2016, 8, 448-461. [CrossRef]

22. Hogg, R.; Coghlan, S.M.; Zydlewski, J. Anadromous sea lampreys recolonize a maine coastal river tributary after dam removal. Trans. Am. Fish. Soc. 2013, 142, 1381-1394. [CrossRef]

23. Gillette, D.P.; Daniel, K.; Redd, C. Fish and Benthic Macroinvertebrate Assemblage Response to Removal of a Partially Breached Lowhead Dam. River Res. Appl. 2016, 32, 1776-1789. [CrossRef]

24. Shaffer, J.A.; Juanes, F.; Quinn, T.P.; Parks, D.; McBride, T.; Michel, J.; Naumann, C.; Hocking, M.; Byrnes, C. Nearshore fish community responses to large scale dam removal: Implications for watershed restoration and fish management. Aquat. Sci. 2017, 79, 643-660. [CrossRef] 
25. Poulos, H.M.; Chernoff, B. Effects of Dam Removal on Fish Community Interactions and Stability in the Eightmile River System, Connecticut, USA. Environ. Manag. 2017, 59, 249-263. [CrossRef]

26. Ohtsuki, K.; Iyooka, H.; Nihei, Y.; Yoshimori, Y.; Nakamura, S.; Onikura, N. Sediment erosion and deposition in the former Arase dam reservoir under the dam removal project. Ann. J. Hydraul. Eng. JSCE 2016, 72, I_853-I_858.

27. Ohmoto, T.; Hirakawa, R. Studies of Arase dam for streambed sediment and flow configuration. Ann. J. Hydraul. Eng. JSCE 2013, 72, I_1057-I_1062.

28. Ohtsuki, K.; Kawasaki, T.; Nihei, Y.; Onikura, N. Non-uniform suspended-sediment transport in Kumagawa river under flooding conditions. Ann. J. Hydraul. Eng. JSCE 2013, 69, I_1063-I_1068.

29. Kobayashi, S.; Sumi, T.; Takemon, Y. Habitat function of a gravel bar formed downstream after a dam removal. Adv. River Eng. 2016, 22, 463-468.

30. Shirakawa, T.; Gouda, M.; Takimoto, T.; Takahashi, E. Channel responses to sediment replenishment to downstream rivers in Nagayasuguchi Dam reservoir sedimentation management. Civ. Eng. J. 2016, 58, $36-41$.

31. Okano, M.; Kikui, M.; Ishida, H.; Sumi, T. Study on Reservoir Sediment Excavation Management and Sediment Replenishment to Downstream Rivers. J. Jpn. Soc. Dam Eng. 2005, 15, 200-215.

32. Musashi, Y.; Shiuchi, M.; Yamashita, M.; Takebayashi, H.; Yuki, T.; Kamata, M.; Akamatsu, Y.; Kawaguchi, Y.; Nakata, Y. Development of numerical model on transport process of replenished sediment and its application. Ann. J. Hydraul. Eng. JSCE 2011, 67, I_817-I_822. [CrossRef]

33. Tashiro, T.; Okuda, C.; Tsujimoto, T. Impacts of riverbed armoring below dam and their mitigation due to gravel addition on habitat of benthic fish community. Ann. J. Hydraul. Eng. JSCE 2014, 70, I_1321-I_1326.

34. Yamada, K.; Tashiro, T.; Tsujimoto, T. Effects of sediment replenishment on stream ecosystem below dam and reservoir: Their verification with particulate organic matters, aquatic organisms and their stable isotope ratios of carbon and nitrogen. Limnol. Tokai Reg. Jpn. 2014, 64, 11-21.

35. Nishita, M.; Azami, K.; Ishizawa, N.; Kumazawa, K.; Nakazawa, S. Changes in physical habitat and benthic animals in the Miharu Dam downstream river in response to river regulation and sediment replenishment after initial impoundment: The result of 11 years monitoring. Ecol. Civ. Eng. 2011, 14, 63-74. [CrossRef]

36. Tanaka, N.; Furusato, E. Annual changes in community dynamics of invertebrate in gravel bed river downstream of a dam and the change in movability of bed material in low flow channel after artificial sand supply. Ann. J. Hydraul. Eng. JSCE 2014, 70, I_1327-I_1332.

37. Katano, I.; Negishi, J.; Minagawa, T.; Doi, H.; Kayaba, Y. Extraction of indicator species to test restoration effects by sediment replenishments in downstream reaches of dam. Adv. River Eng. 2010, 16, 519-522.

38. Sakka, S.; Takeuchi, H.; Aoshima, D.; Saito, A. Investigation on the characteristics of sediment outflow during a flood at the dry dam. J. Jpn. Soc. Dam Eng. 2009, 19, 29-40.

39. Sumi, T.; Ishida, H.; Satake, Y. Sediment transport monitoring in in-stream flood mitigation dam by RFID technology. Ann. J. Hydraul. Eng. JSCE 2012, 68, I_1071-I_1076.

40. Murakami, T.; Hodoki, Y. Comparison of Population Density and Species Composition of Aquatic Insect between the Upstream and Downstream Reaches of a Flood Control Dam without Impoundment; A Case Study of the Masuda-gawa Dam in Shimane Prefecture. Jpn. J. Nagoya Women's Univ. Home Econ. Nat. Sci. Humanit. Soc. Sci. 2011, 57, 75-79.

41. Itsukushima, R.; Ohtsuki, K.; Sato, T.; Tanaka, W. Sediment properties in steep stream associated with the sediment replenishment by check dam drain outlet opening. Ann. J. Hydraul. Eng. JSCE 2018, 62, I_913-I_918. [CrossRef]

42. Japanese Standards Association. JIS K 0102 Testing Methods for Industrial Wastewater; Japanese Standards Association: Tokyo, Japan, 2008.

43. Minchin, P.R. An evaluation of the relative robustness of techniques for ecological ordination. Vegetatio 1987, 69, 89-107. [CrossRef]

44. Bray, J.R.; Curtis, J.T. An ordination of upland forest communities of southern Wisconsin. Ecol. Monogr. 1957, 27, 325-349. [CrossRef]

45. Whittaker, R.H. Evolution and measurement of species diversity. Taxon 1972, 21, 213-251. [CrossRef]

46. Evans, J.E.; Mackey, S.D.; Gottgens, J.F.; Gill, W.M. Lessons from a dam failure. Ohio J. Sci. 2000, 100, $121-131$.

47. Burroughs, B.A.; Hayes, D.B.; Klomp, K.D.; Hansen, J.F.; Mistak, J. Effects of Stronach Dam removal on fluvial geomorphology in the Pine River, Michigan, United States. Geomorphology 2009, 110, 96-107. [CrossRef] 
48. Foley, M.M.; Bellmore, J.R.; O'Connor, J.E.; Duda, J.J.; East, A.E.; Grant, G.E.; Anderson, C.W.; Bountry, J.A.; Collins, M.J.; Connolly, P.J.; et al. Dam removal: Listening in. Water Resour. Res. 2017, 53, 5229-5246. [CrossRef]

49. Ferrer-Boix, C.; Martín-Vide, J.P.; Parker, G. Channel evolution after dam removal in a poorly sorted sediment mixture: Experiments and numerical model. Water Resour. Res. 2014, 50, 8997-9019. [CrossRef]

50. Ibisate, A.; Ollero, A.; Ballarín, D.; Horacio, J.; Mora, D.; Mesanza, A.; Ferrer-Boix, C.; Acín, V.; Granado, D.; Martín-Vide, J.P. Geomorphic monitoring and response to two dam removals: Rivers Urumea and Leitzaran (Basque Country, Spain). Earth Surf. Proc. Land. 2016, 41, 2239-2255. [CrossRef]

51. Randle, T.J.; Bountry, J.A.; Ritchie, A.; Wille, K. Large-scale dam removal on the Elwha River, Washington, USA: Erosion of reservoir sediment. Geomorphology 2015, 246, 709-728. [CrossRef]

52. Hatano, K.; Takemon, Y.; Ikebuchi, S. Evaluation of the impact of water-storage dam on lower river ecosystems-Response of the substrate structure and benthos communities. Disaster Prev. Res. Inst. Annu. B 2003, 46, 851-866.

53. Fuller, R.L.; Griego, C.; Muehlbauer, J.D.; Dennison, J.; Doyle, M.W. Response of stream macroinvertebrates in flow refugia and high-scour areas to a series of floods: A reciprocal replacement study. J. N. Am. Benthol. Soc. 2010, 29, 750-760. [CrossRef]

54. Stanley, E.H.; Luebke, M.A.; Doyle, M.W.; Marshall, D.W. Short-term changes in channel form and macroinvertebrate communities following low-head dam removal. J. N. Am. Benthol. Soc. 2002, 21, 172-187. [CrossRef]

55. Loosanoff, V.L.; Tommers, F.D. Effect of suspended silt and other substances on rate of feeding of oysters. Science 1948, 107, 69-70. [CrossRef] [PubMed]

56. Auld, A.H.; Schubel, J.R. Effects of suspended sediment on fish eggs and larvae: A laboratory assessment. Estuar. Coast. Mar. Sci. 1978, 6, 153-164. [CrossRef]

57. Hori, M.; Wakabayashi, H.; Yamamoto, K.; Kato, S.; Kojima, T. Assessment of influence of sediment flushing from dam on fishery products. Bull. Soc. Sea Water Sci. Jpn. 2007, 61, 352-359.

(C) 2019 by the authors. Licensee MDPI, Basel, Switzerland. This article is an open access article distributed under the terms and conditions of the Creative Commons Attribution (CC BY) license (http:/ / creativecommons.org/licenses/by/4.0/). 